\title{
Localization of cyclooxygenase and production of prostaglandins in bovine spermatozoa
}

\author{
Y. Shalev ${ }^{1}$, M. Shemesh ${ }^{2,3 *}$, T. Levinshal ${ }^{1}$, S. Marcus ${ }^{2}$ and \\ H. Breitbart ${ }^{1}$ \\ ${ }^{1}$ Department of Life Sciences, Bar-Ilan University, Ramat-Gan 52900, Israel, ${ }^{2}$ Department of Hormone \\ Research, Kimron Veterinary Institute, Beit Dagan, 50250, Israel; and ${ }^{2}$ Koret School of Veterinary \\ Medicine, Hebrew University of Jerusalem, Israel
}

\begin{abstract}
Ejaculated bovine spermatozoa were examined for their capacity to synthesize prostaglandins $\mathrm{E}_{2}$ and $\mathrm{F}_{2 \alpha}\left(\mathrm{PGE}_{2}, \mathrm{PGF}_{2 \alpha}\right)$. It was found that in the absence of exogenous substrate, arachidonic acid, basal $\mathrm{PGF}_{2 \alpha}$ production was less than that of $\mathrm{PGE}_{2}$. However, addition of $61 \mu \mathrm{mol}$ arachidonic acid $1^{-1}$ resulted in at least a twofold increase in $\mathrm{PGE}_{2}$ and $\mathrm{PGF}_{2 \alpha}$ above control values ( $1.3 \mathrm{ng}$ and $0.3 \mathrm{ng}$ per $10^{8}$ spermatozoa, respectively). Addition of calcium and the calcium ionophore A23187 to the incubation medium did not cause a significant increase in the production of either PG. The presence of indomethacin (100-200 $\mu \mathrm{g} \mathrm{ml}^{-1}$ ) caused a 50-70\% inhibition of the production of both PGs. Activity of cyclooxygenase was determined by western blot analysis, using a specific polyclonal antiserum, and by fluorescence immunohistochemistry using a monoclonal antibody. The western blot displayed a clear signal for the presence of cyclooxygenase in ejaculated and epididymal spermatozoa. The immunohistochemical studies showed that the enzyme is localized in the apical region of the head, the post-acrosomal region and the mid-piece of the tail. Since the synthesis of PGs in the absence of exogenous arachidonic acid is low, the effect of melittin, a known phospholipase $A_{2}$ activator, on PG production was examined. Incubation of spermatozoa with melittin produced a threefold increase in $\mathrm{PGE}_{2}$ and a sixfold increase in $\mathrm{PGF}_{2 a}$. Staurosporine, a protein kinase $\mathrm{C}$ inhibitor, inhibited the effect of melittin indicating that activation of phospholipase $A_{2}$ by protein kinase $C$ is an obligatory step in PG synthesis by bovine spermatozoa. To determine the physiological role of PG synthesis by bovine spermatozoa the effect of $\mathrm{PGE}_{2}$ and $\mathrm{PGF}_{2 \alpha}$ on $\mathrm{Ca}^{2+}$ uptake was examined. $\mathrm{PGE}_{2}$, but not $\mathrm{PGF}_{2 \alpha^{\prime}}$ increased the $\mathrm{Ca}^{2+}$ uptake linearly during the first $10 \mathrm{~min}$ of incubation. These data provide evidence that bovine spermatozoa can synthesize prostaglandins in the presence of arachidonic acid or melittin. Furthermore, it was demonstrated that the spermatozoa contain the key enzyme for prostaglandin synthesis, cyclooxygenase.
\end{abstract}

\section{Introduction}

Prostaglandins (PGs) have been reported to be involved in all of the stages of sperm maturation, from spermatogenesis to the acrosomal reaction (for review see Hayashi et al., 1988). It has also been reported that PGs may inhibit (Cohen et al., 1977) or stimulate (Schlegel et al, 1981) sperm motility. Meizel and Turner (1984) reported that $\mathrm{PGE}_{1}$ stimulates the acrosome reaction in hamster spermatozoa and Joyce et al. (1987) reported than exogenous PGE can overcome inhibition of the acrosome reaction by indomethacin in guinea-pigs. Although nearly all reproductive tissues examined have been shown to produce PGs (semen: Gerozissi and Dray, 1981; uterine fluid: Harrison et al., 1987; Graaffian follicles: LaMaire et al, 1975; Fallopian tubes: Warnes et al., 1978), there has been only one recent report on PG synthesis by human spermatozoa (Roy and

*Correspondence.

Received 22 November 1993.
Ratnam, 1992), but Shalev et al. (1992) were the first to report this activity in intact bovine spermatozoa. The present studies were conducted ( 1 ) to determine whether intact bovine spermatozoa can synthesize $\mathrm{PGE}_{2}$ or $\mathrm{PGF}_{2 \alpha^{\prime}}$ (2) to localize cyclooxygenase using an immunofluorescent technique; (3) to confirm the existence of cyclooxygenase in spermatozoa homogenates by western blot analysis; (4) to elucidate the regulatory mechanism of PG synthesis by bovine sperematozoa; and (5) to determine the role of PGs in $\mathrm{Ca}^{2+}$ uptake by spermatozoa.

\section{Materials and Methods}

\section{Materials}

Arachidonic acid, indomethacin, melittin, staurosporine, calcium ionophore, prostaglandins, $3(\mathrm{~N}$-morpholino) propanesulfonic acid (MOPS), tergitol type NP-40, phenylmethylsulfonyl fluoride were all purchased from Sigma (St Louis, 
Table 1. Production of prostaglandins (PGs) by bovine spermatozoa in response to increasing doses of arachidonic acid

\begin{tabular}{ccc}
\hline & \multicolumn{2}{c}{$\begin{array}{c}\text { Prostaglandin secretion } \\
\left(\text { pg per } 10^{8} \text { spermatozoa per } 3 \mathrm{~h}\right)\end{array}$} \\
\cline { 2 - 3 } Arachidonic acid $\left(\mu \mathrm{mol} \mathrm{l}^{-1}\right)$ & $\mathrm{PGF}_{2 a}$ & $\mathrm{PGE}_{2}$ \\
\hline & & \\
\hline 0 & $50 \pm 12$ & $437 \pm 31$ \\
2.4 & $65 \pm 6$ & $453 \pm 30$ \\
12.6 & $93 \pm 12$ & $671 \pm 31$ \\
61.0 & $153 \pm 18^{\mathrm{a}}$ & $1156 \pm 109^{\mathrm{b}}$ \\
122.0 & $500 \pm 31$ & $2515 \pm 124$ \\
\hline
\end{tabular}

Results are expressed as means $( \pm$ SEM). Five replicates were carried out for each treatment in each experiment.

Significantly different from control: ${ }^{\mathrm{a}} P<0.01 ;{ }^{\mathrm{b}} P<0.05$.

MO). GF/C filters were purchased from Tamar Incorporation (Jerusalem). Arachidonic acid and indomethacin were dissolved in ethanol and evaporated to dryness in a vacuum before use. Labelled $\mathrm{PGF}_{2 \alpha}\left[5,6,8,9,11,12,14,15-{ }^{3} \mathrm{H}\right] \quad\left(164 \mathrm{Ci} \mathrm{mmol} \mathrm{m}^{-1}\right)$, $\mathrm{PGE}_{2}\left[5,6,8,9,11,12,14,15-{ }^{3} \mathrm{H}\right]\left(191 \mathrm{Ci} \mathrm{mmol}{ }^{-1}\right)$ and ${ }^{45} \mathrm{CaCl}_{2}$ (10-40 $\left.\mathrm{Ci} \mathrm{mg}{ }^{-1}\right)$ were purchased from Amersham International (Amersham, Buckinghamshire). Polyclonal antibody for prostaglandin synthetase (cyclooxygenase) was produced in our laboratory by inoculating rabbits with purified ram seminal vesicle prostaglandin synthetase (Oxford Biochemicals, Oxford, MI) as previously described (Izhar et al., 1992). Horseradish peroxidase conjugated anti-rabbit IgG was purchased from Biomakor (Nes Ziona, Israel). Monoclonal antibodies for cyclooxygenase were purchased from Cayman Chemical (Ann Arbor, MI). The antigen was purified cyclooxygenase from sheep seminal vesicles (crossreactivity: human, rat, bovine and most mammalian species). The second antibody was fluorescein isothiocyanate anti-mouse IgG (Sigma). Since the specificity of the polyclonal anti-cyclooxygenase was not evaluated for the immunocytochemistry study, a well-characterized commercial monoclonal antibody was used for the localization of cyclooxygenase in the cell and the polyclonal antiserum was used only for the western blot studies.

\section{Sperm preparation}

Fresh ejaculated bull semen, collected using an artificial vagina (Artificial Insemination Center, Hafetz Haim), was immediately diluted ( $1: 1, v: v)$ with media containing $110 \mathrm{mmol}$ $\mathrm{NaCl} \mathrm{l}^{-1}, 5 \mathrm{mmol} \mathrm{KCl}^{-1}$ and $10 \mathrm{mmol} \mathrm{MOPS}{ }^{-1}$ (pH 7.4) (NKM media). Bovine epididymides were obtained from local abattoirs. Epididymal spermatozoa were collected and washed as described by Babcock et al. (1976). The cells were washed with NKM media, centrifuged at $780 \mathrm{~g}$ for $10 \mathrm{~min}$ (three times) and resuspended in TALP (Lax et al., 1990) to a final concentration of $10^{8}$ cells $\mathrm{ml}^{-1}$. Only those samples with a minimum of $70 \%$ motile spermatozoa were used. The TALP medium contained (in mmol l-1) $94.3 \mathrm{NaCl}, 4.0 \mathrm{KCl}, 0.7 \mathrm{Na}_{2} \mathrm{HPO}_{4}$, $25.9 \mathrm{NaHCO}_{3}, 0.5 \mathrm{MgCl}_{2} \cdot 6 \mathrm{H}_{2} \mathrm{O}, 12.8$ glucose, 1.3 pyruvate, 7.6 lactate, 20 Hepes ( $\mathrm{pH} 7.4$ ) plus $3.0 \mathrm{mg} \mathrm{BSA} \mathrm{ml}^{-1}$ and $10 \mathrm{iu}$ penicillin $\mathrm{ml}^{-1}$.

\section{Cell incubations}

Spermatozoa were incubated for $3 \mathrm{~h}$ in TALP medium at $37^{\circ} \mathrm{C}$ in an atmosphere of $5 \% \mathrm{CO}_{2}: 95 \%$ air. Samples were then centrifuged at $780 \mathrm{~g}$ for $10 \mathrm{~min}$ at $4^{\circ} \mathrm{C}$ and the supernatants were extracted with ethyl acetate acidified with $\mathrm{HCl}$. After evaporation under vacuum, the dried residues were stored at $-20^{\circ} \mathrm{C}$ and redissolved in $0.5 \mathrm{ml}$ steroid buffer (PBS plus $0.1 \%$ gelatin) before the radioimmunoassay.



Fig. 1. Time course study of conversion of arachidonic acid to (a) prostaglandin $\mathrm{F}_{2 \alpha}\left(\mathrm{PGF}_{2 a}\right)$ and (b) $\mathrm{PGE}_{2}$ by bovine spermatozoa. Spermatozoa were incubated with $61 \mu \mathrm{mol}$ arachidonic acid $\mathrm{I}^{-1}$. Mean $\mathrm{PGF}_{2 a}$ and $\mathrm{PGE}_{2}$ production after $3 \mathrm{~h}$ incubation was significantly greater than production at zero time, $P<0.01$. 


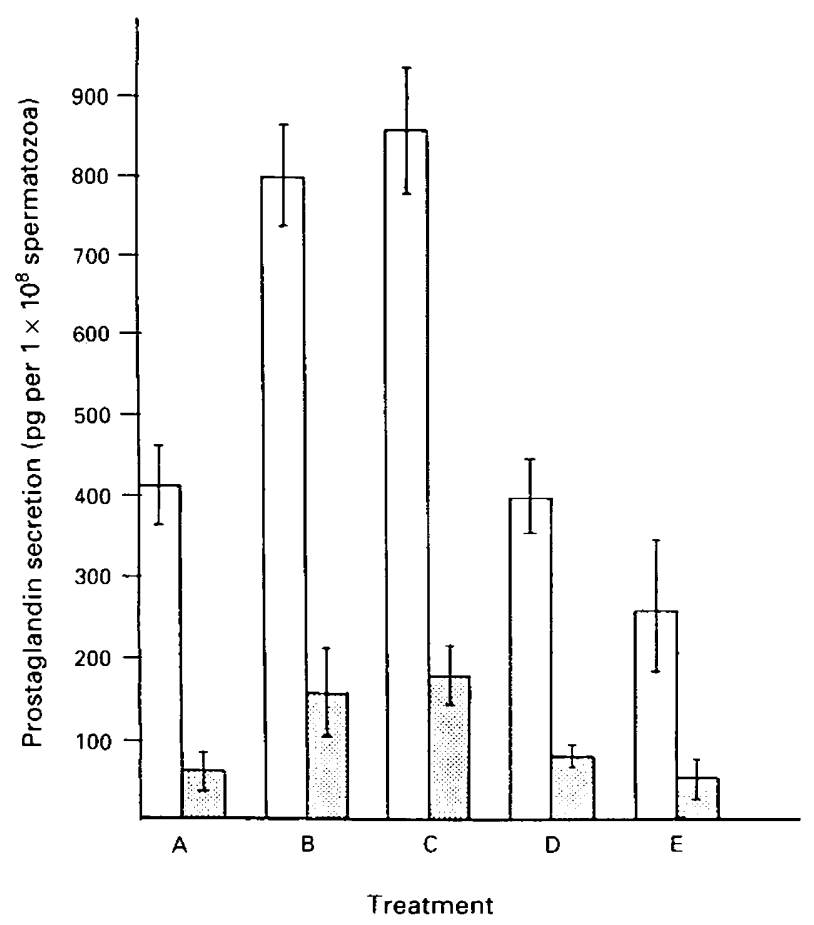

Fig. 2. Effect of $\mathrm{Ca}^{2+}$, arachidonic acid and indomethacin on prostaglandins (PGs) $\mathrm{PGF}_{2 a}$ and $\mathrm{PGE}_{2}$ accumulation in the culture media containing bovine spermatozoa. Spermatozoa were prepared and incubated in the following media: $\mathrm{A}$ : control media containing $2 \mathrm{mmol}$ $\mathrm{CaCl}_{2} \mathrm{l}^{-1}$; $\mathrm{B}$ : addition of $61 \mu \mathrm{mol}$ arachidonic acid $1^{-1}$ to medium containing calcium; $C$ : addition $61 \mu \mathrm{mol}$ arachidonic acid $1^{-1}$ in the absence of calcium; $\mathrm{D}$ : addition of $10 \mu \mathrm{g}$ indomethacin $\mathrm{ml}^{-1}$ to $\mathrm{B}$; $\mathrm{E}$ : addition of $200 \mu \mathrm{g}$ indomethacin $\mathrm{ml}^{-1}$ to $\mathrm{B}$. ( $\square$ ) $\mathrm{PGE}_{2}$ (圆) $\mathrm{PGF}_{2 \mathrm{a}}$. There was no difference in amount of PGs formed in the control media in the absence or presence of calcium (data not shown). Production of $P F_{2 \alpha}$ and PGE was significantly $(P<0.01)$ inhibited by 50 and $70 \%$, respectively, by indomethacin.

\section{Treatments}

Arachidonic acid was added at the concentration of $61 \mu \mathrm{mol}$ $1^{-1}$ since this concentration has been shown by Meizel and Turner (1984) to be optimal for the acrosomal reaction in hamster spermatozoa. Indomethacin was added at the concentration of $100 \mu \mathrm{g} \mathrm{ml}^{-1}$ since Joyce et al. (1987) showed that this concentration inhibited the acrosomal reaction. Preliminary experiments showed that this concentration caused a $50 \%$ inhibition of prostaglandin synthesis by spermatozoa. Melittin was added at $20 \mu \mathrm{g} \mathrm{ml}^{-1}$ since this concentration resulted in a maximal stimulation of PG production over the range of $1.25-20 \mu \mathrm{g} \mathrm{ml}^{-1}$. Staurosporine was used at a concentration of $10^{-9}-10^{-10} \mathrm{~mol} \mathrm{l}^{-1}$; higher concentrations have been reported to be toxic to rat liver cells (Levine, 1990). Neither indomethacin nor staurosporine treatments had any effect on spermatozoa motility or forward progression.

In the calcium-uptake experiments, $\mathrm{PGE}_{2}$ was tested at a concentration of $1.3 \mathrm{ng} \mathrm{ml}^{-1}$ (the amount produced by spermatozoa cells after $3 \mathrm{~h}$ of incubation) and $40 \mathrm{ng} \mathrm{ml}^{-1}$ (concentration in seminal fluid). $\mathrm{PGF}_{2 \alpha}$ was tested at $350 \mathrm{pg} \mathrm{ml}^{-1}$ (the amount produced by spermatozoa cells after $3 \mathrm{~h}$ of incubation) and $0.25 \mu \mathrm{g} \mathrm{ml}^{-1}$ (concentration in seminal fluid). The PGs

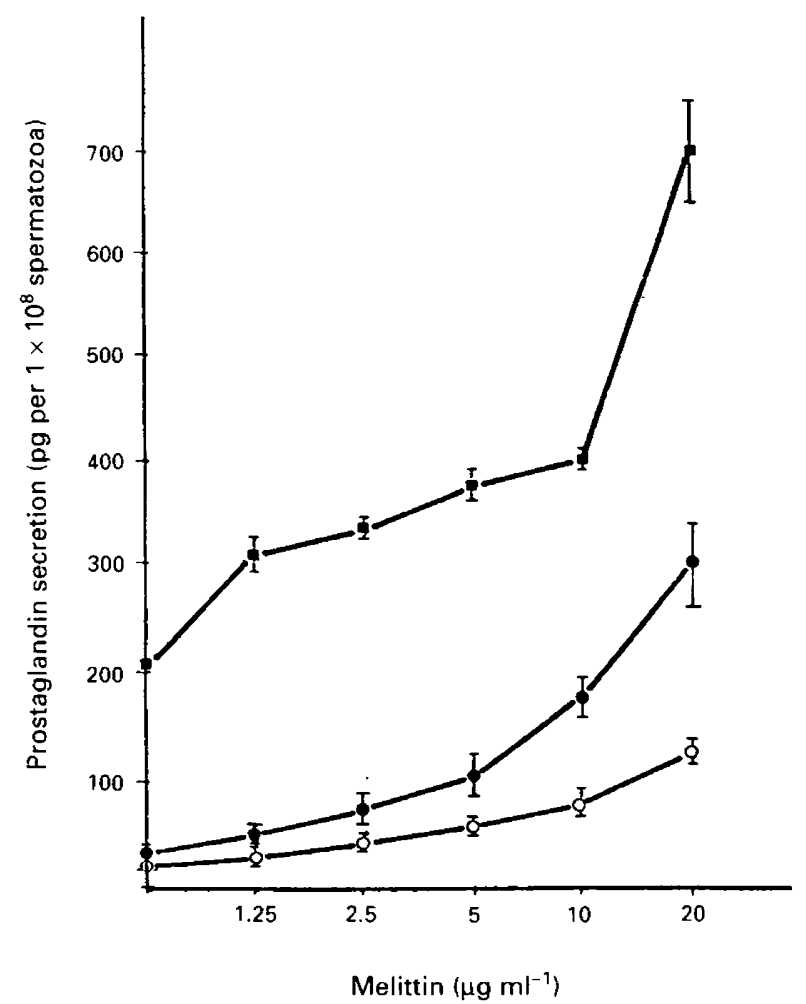

Fig. 3. Effect of melittin on production of prostaglandins (PGs) by bovine spermatozoa. Arachidonic acid was not added to the incubation media. Melittin was added in the range $0-20 \mu \mathrm{g} \mathrm{ml}^{-1}$ in the presence of $(\bullet) 2 \mathrm{mmol} \mathrm{CaCl} \mathrm{I}^{-1}$ for $\mathrm{PGF}_{2 a}(0)$ without calcium and (a) for $\mathrm{PGE}_{2}$ in the presence of calcium.

were incubated with spermatozoa for 10 min before the addition of labelled calcium. In the experiments with indomethacin, the inhibitor was added $5 \mathrm{~min}$ before the addition of the PG to be tested.

\section{Radioimmunoassay of prostaglandins}

The dried residues of extracted $\mathrm{PGF}_{2 a}$ and $\mathrm{PGE}_{2}$ were dissolved in steroid buffer and assayed directly by radioimmunoassay as described by Shemesh et al. (1979).

\section{Preparation of spermatozoa lysates}

Spermatozoa $\left(1 \times 10^{8} \mathrm{ml}^{-1}\right)$ were washed twice with cold PBS. The pellet was suspended in the lysis buffer which contained (mmol l-1): 10 Tris- $\mathrm{HCl}, \mathrm{pH} 7.5 ; 0.5 \mathrm{MgCl}_{2} ; 2$ EGTA, 1 phenylmethylsulfonyl fluoride plus $1 \%$ NP-40 and $0.1 \%$ SDS. The lysate was incubated for $15 \mathrm{~min}$ in ice, centrifuged $(13000 \mathrm{~g}, 10 \mathrm{~min})$ and the supernatant stored at $-20^{\circ} \mathrm{C}$.

\section{SDS-PAGE}

The supernatant was diluted 1:I in sample buffer $0.05 \mathrm{~mol}$ Tris- $\mathrm{HCl} 1^{-1}, \mathrm{pH} 6.8,0.5 \%$ SDS, $10 \%$ mercaptoethanol, $20 \%$ glycerol, $0.001 \%$ bromophenol blue) and heated for $5 \mathrm{~min}$ at 


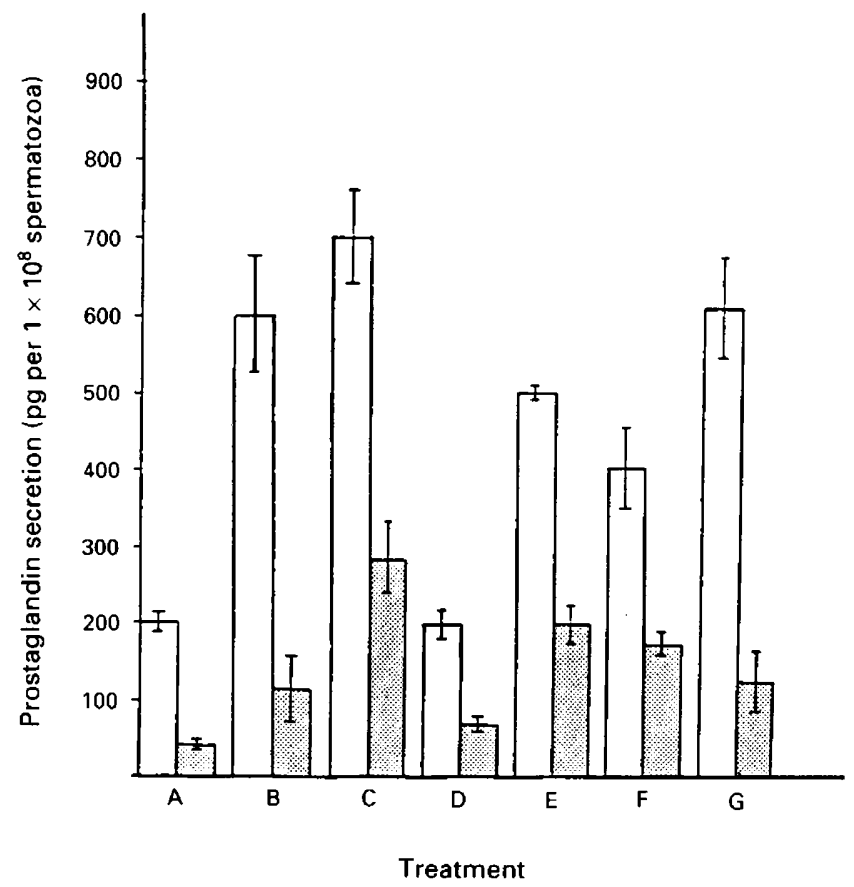

Fig. 4. Effect of staurosporine or indomethacin on melittin-stimulated, or arachidonic acid-stimulated production of prostaglandins (PGs) by bovine spermatozoa. $\mathrm{PGF}_{2 a}$ and $\mathrm{PGE}_{2}$ were measured in the media following $3 \mathrm{~h}$ of incubation. Treatments: A: TALP $+2 \mathrm{mmol} \mathrm{CaCl}$ $\mathrm{I}^{-1}$; $\mathrm{B}$ : as $\mathrm{A}$ plus $61 \mu \mathrm{mol}$ arachidonic acid $\mathrm{l}^{-1}$; $\mathrm{C}$ : as A plus $20 \mu \mathrm{g}$ melittin $\mathrm{ml}^{-1}$; $\mathrm{D}$ : as $C$ plus $100 \mu \mathrm{g}$ indomethacin $\mathrm{ml}^{-1}$; $\mathrm{E}$ : as $\mathrm{C}$ plus $I \times 10^{-10} \mathrm{~mol}$ staurosporine $\mathrm{I}^{-1} ; \mathrm{F}$; as $\mathrm{C}$ plus $\mathrm{I} \times 10^{-9} \mathrm{~mol}$ stauro-

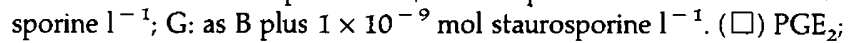
(圆) $\mathrm{PGF}_{2 \alpha}$. The stimulatory effect of melittin on $\mathrm{PG}$ synthesis was significantly inhibited $\left(P<0.01\right.$ for $\mathrm{PGE}_{2} ; P<0.02$ for $\left.\mathrm{PGF}_{2 \alpha}\right)$ by staurosporine in a dose-dependent manner.

$100^{\circ} \mathrm{C}$. The sample was subjected to electrophoresis in a one-dimensional 9\% SDS-PAGE slab gel topped with 5\% stacking gel (Izhar et al., 1992). Molecular weight markers were used as standards. All electrophoretic reagents were purchased from Bio-Rad Laboratories (Richmond, CA).

\section{Western blot analysis}

Microsomes from bovine seminal vesicles were separated on SDS-PAGE and electroblotted onto nitrocellulose paper (Amersham) as described by Izhar et al. (1992). The paper was then treated with rabbit anti-PGS polyclonal antisera (1:100) followed by incubation with goat anti-rabbit IgG conjugated to horseradish peroxidase $(1: 2000)$ and a colour reaction performed. Protein was determined using $\gamma$-globulin as a reference standard and a protein dye-binding method (Bio Rad Lab.).

\section{Immunocytochemistry studies}

Bovine spermatozoa were air-dried on slides at room temperature and fixed in absolute methanol for $15 \mathrm{~min}$. After rehydration with $\mathrm{PBS}$, cells were incubated with the monoclonal antibody (1:500) for $30 \mathrm{~min}$. The slides were then

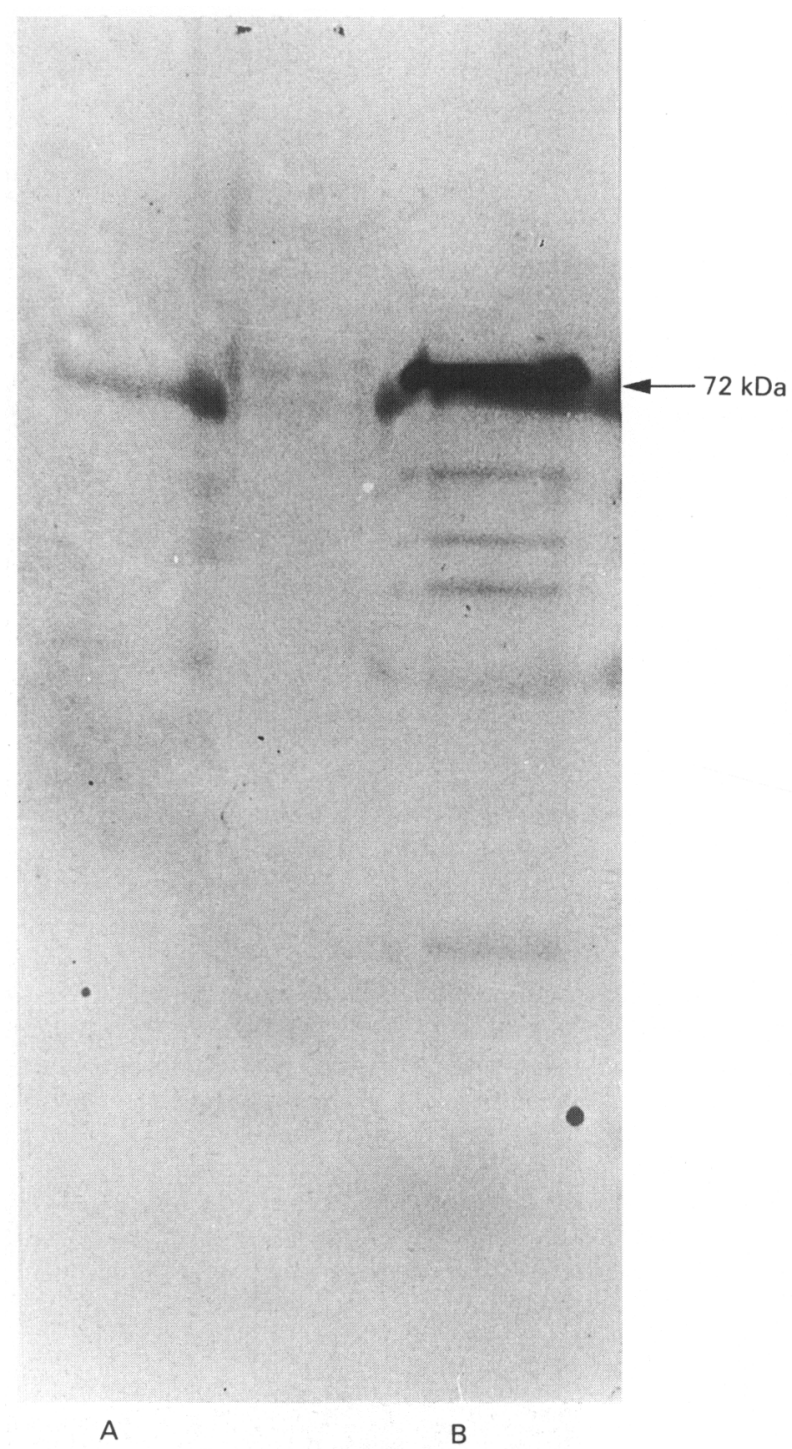

Fig. 5. Western blot analysis of cyclooxygenase. Lane A: $100 \mu \mathrm{g}$ of spermatozoa homogenate was applied to SDS-PAGE. Lane B: $25 \mu \mathrm{g}$ protein from bovine seminal vesicle microsomes was used as internal positive marker. Cyclooxygenase (arrow) was readily detectable in the homogenate of bovine ejaculated spermatozoa and in the seminal vesicle microsomes.

washed extensively with PBS and incubated with the fluorescein isothiocyanate antibody (I:5) for $30 \mathrm{~min}$. Slides were again washed with PBS and examined under a fluorescent microscope. Control slides were incubated with normal mouse serum (1:500) instead of the monoclonal antibody or with monoclonal antibody preadsorbed onto purified cyclooxygenase from ram seminal vesicles.

\section{${ }^{45} \mathrm{Ca}^{2+}$ uptake measurements}

Fresh ejaculated spermatozoa were prepared as described above. ${ }^{45} \mathrm{Ca}^{2+}$ uptake was determined using the filtration technique described by Ben-Av et al. (1988) with some modifications. The final concentration of washed spermatozoa 

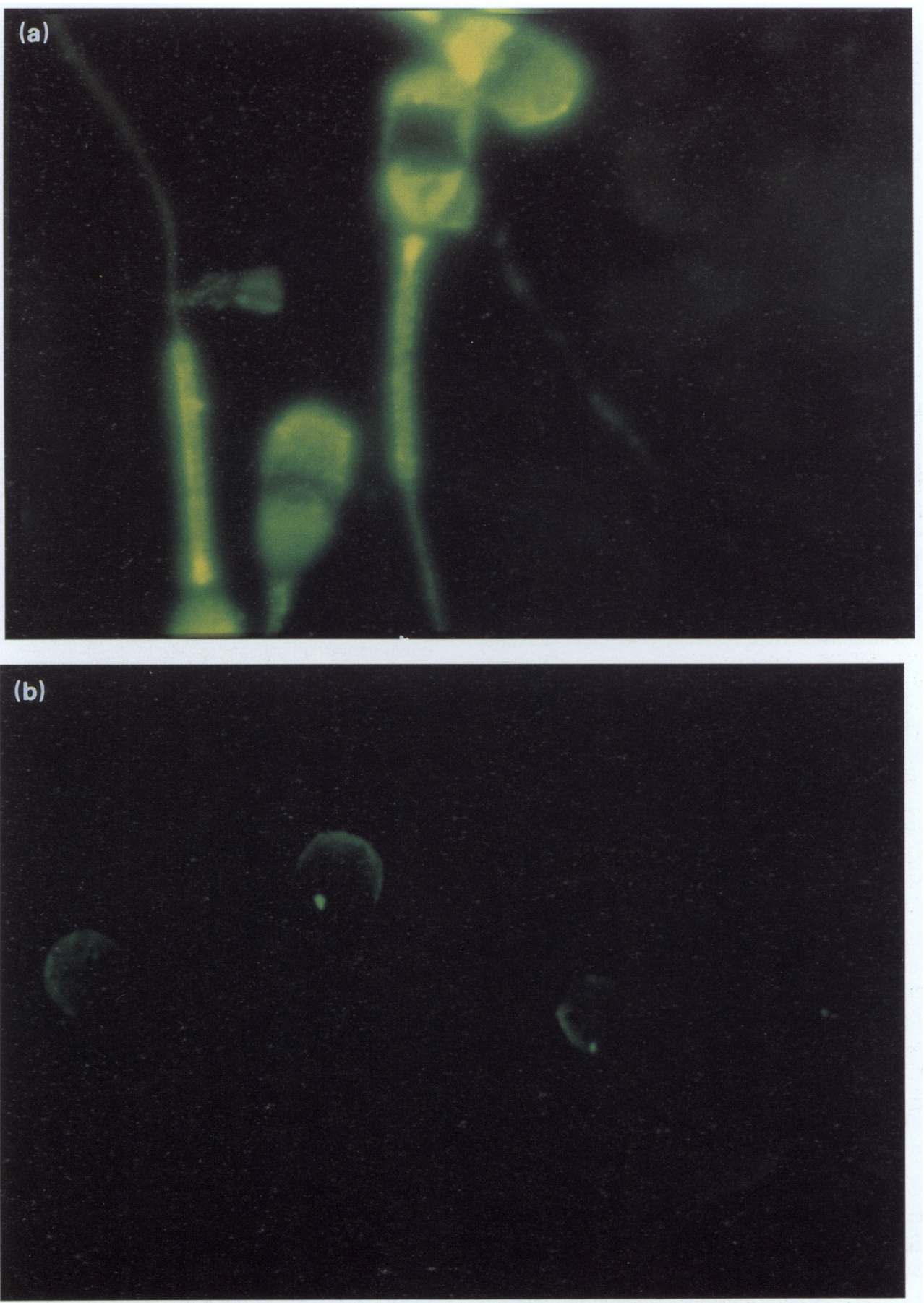

Fig. 6. Localization of cyclooxygenase in bovine spermatozoa. (a) Spermatozoa were treated with monoclonal antibody to cyclooxygenase and then with a fluorescein isothiocyanate second antibody. Cyclooxygenase was localized in the apical region of the spermatozoa head, the post-acrosomal region and the mid-piece of the tail. (b) Control spermatozoa treated with normal mouse serum or with preadsorbed antiserum and then with the fluorescein isothiocyanate second antibody.

was $3 \times 10^{*}$ cells in $1 \mathrm{ml}$ of NKM and $0.5 \mu \mathrm{Ci}{ }^{+5} \mathrm{CaCl}_{2}$ and 2 mmol $\mathrm{CaCl}_{2} \mathrm{I}^{-1}$ were added to each tube. The time of addition was taken as zero time (representing the nonspecific binding) and aliquots were taken at 2, 4, 6, 8, 10, 12 and 15 min intervals and applied to GF/C filters (Ben-Av of al., 1988). The filters were prewashed with the washing buffer
(150 $\mathrm{mmol} \mathrm{NaCl}^{-1}$; 2 mmol EGTA $~^{-1}{ }^{1} ; 10 \mathrm{mmol}$ Tris I I, $\mathrm{pH}$ 7.4). The cells were trapped on the filters and washed three times with ice-cold washing buffer and placed in scintillation vials. Four millilitres of liquiscint was added to each vial and the beta radiation counted in a Packard Scintillation Counter. 


\section{Statistical analysis}

Values for $\mathrm{PGF}_{2 \alpha}$ and $\mathrm{PGE}_{2}$ are expressed as $\mathrm{pg}$ PG produced per $10^{8}$ cells $\mathrm{ml}^{-1}(3 \mathrm{~h})^{-1}( \pm$ SEM). Pooled results from three to five independent experiments using multiple donors are presented. In each experiment there were five replicates for each treatment. Data were analysed using Student's $t$ test.

\section{Results}

The effect of arachidonic acid concentrations on $P G E$ and $P G F$ accumulation

To study the effect of increasing substrate concentration on $\mathrm{PGE}_{2}$ and $\mathrm{PGF}_{2 \alpha}$ accumulation by bovine spermatozoa $\left(10^{8} \mathrm{ml}^{-1}\right)$, incubations were performed in the presence of increasing concentrations of arachidonic acid (Table 1 ). $\mathrm{PGE}_{2}$ and $\mathrm{PGF}_{2 \alpha}$ increased linearly concomitant with the increase in the concentrations of arachidonic acid in the incubation medium. At $61 \mu \mathrm{mol}$ arachidonic acid $1^{-1}, \mathrm{PGE}_{2}$ and $\mathrm{PGF}_{2 a}$ accumulations had increased about threefold above basal values. However, $122 \mu \mathrm{mol}$ arachidonic acid $1^{-1}$ (maximum dose of substrate tested in this study) increased $\mathrm{PGE}_{2}$ accumulation by approximately sixfold and $\mathrm{PGF}_{2 \alpha}$ by tenfold above basal values.

To ensure that cyclooxygenase within the spermatozoa rather than within the semen or adhering to the spermatozoa was responsible for PG production, seminal plasma was incubated with arachidonic acid and there was no increase in PG production with time above basal activity.

\section{Time course study of the conversion of arachidonic acid to $P G s$}

The accumulation of $\mathrm{PGE}_{2}$ and $\mathrm{PGF}_{2 \alpha}$ increased linearly for the first $3 \mathrm{~h}$ of incubation in the presence of $61 \mu \mathrm{mol}$ arachidonic acid $\mathrm{l}^{-1}$ (Fig. 1). Since $50 \%$ of the maximum stimulation obtained was seen after $3 \mathrm{~h}$ of incubation, this period was used in subsequent experiments.

Effect of $\mathrm{Ca}^{2+}$, calcium ionophore and indomethacin on arachidonic acid conversion to $P G$

The addition of $0-10 \mu \mathrm{mol}$ calcium ionophore $1^{-1}$ to the medium alone or in combination with $2 \mathrm{mmol} \mathrm{Ca}^{2+} \mathrm{l}^{-1} \mathrm{did}$ not cause any significant increase in PG metabolites (data not shown). The role of cyclooxygenase in the conversion of arachidonic acid to PGs was determined by incubating spermatozoa with arachidonic acid in the presence of indomethacin, an inhibitor of cyclooxygenase. Indomethacin $\left(100-200 \mu \mathrm{g} \mathrm{ml}^{-1}\right)$ was added $10 \mathrm{~min}$ before the addition of arachidonic acid. The production of $\mathrm{PGF}_{2 \alpha}$ and $\mathrm{PGE}_{2}$ was significantly $(P<0.01)$ inhibited by $50 \%$ and $70 \%$, respectively, by indomethacin (Fig. 2).

The effect of melittin on PGE and PGF $2 a$ accumulation in the incubation media

Melittin has been shown to activate phospholipase $\mathrm{A}_{2}$. The effect of increasing concentrations $\left(1.25-20 \mu \mathrm{g} \mathrm{ml}^{-1}\right)$ of

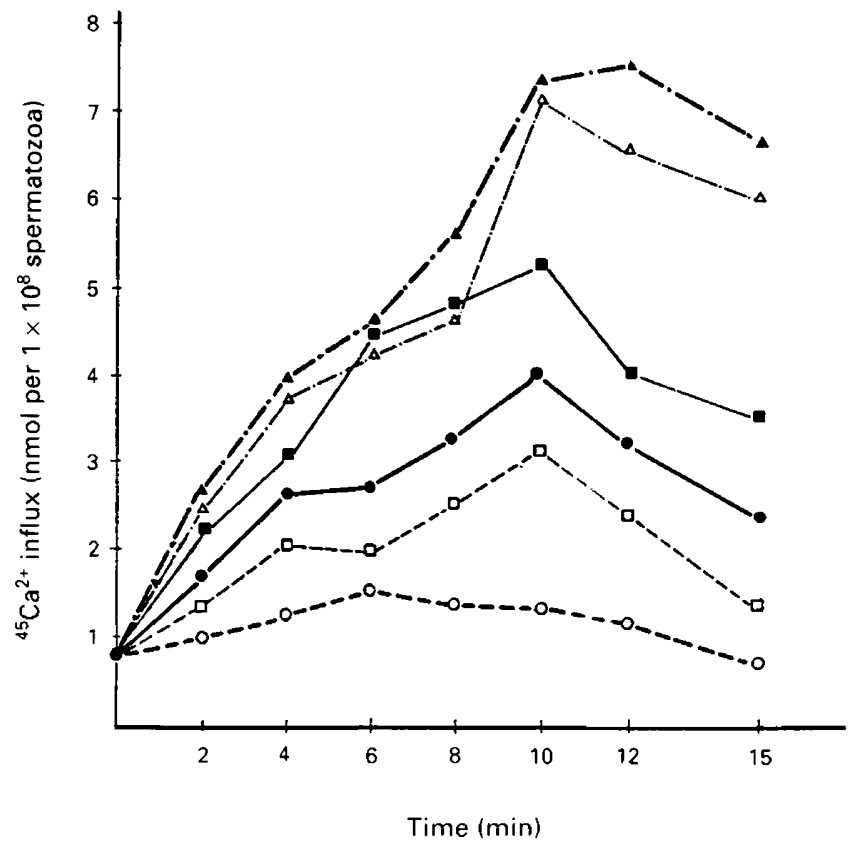

Fig. 7. Effect of prostaglandin E (PGE) or indomethacin, alone and in combination, on calcium uptake by bovine spermatozoa. Spermatozoa

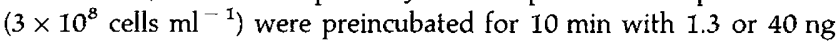
$\mathrm{PGE}_{2} \mathrm{ml}^{-1} .{ }^{45} \mathrm{Ca}^{2+}$ was added at time 0 and aliquots taken at the

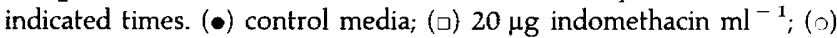
$100 \mathrm{~g}$ indomethacin $\mathrm{ml}^{-1} ;$ (1) $100 \mu \mathrm{g}$ indomethacin $\mathrm{ml}^{-1}$ plus $40 \mathrm{ng} \mathrm{ml}{ }^{-1} \mathrm{PGE}_{2} ;$ (-) $100 \mu \mathrm{g}$ indomethacin $\mathrm{ml}^{-1}$ plus $1.3 \mathrm{ng} \mathrm{PGE}_{2}$ $\mathrm{ml}^{-1} ;(\Delta)$ preincubation with $20 \mu \mathrm{g}$ indomethacin $\mathrm{ml}^{-1}$ for $5 \mathrm{~min}$ followed by $40 \mathrm{ng} \mathrm{PGE}_{2} \mathrm{ml}^{-1}$.

melittin on the accumulation of $\mathrm{PGE}_{2}$ and $\mathrm{PGF}_{2 \alpha}$ in the absence of exogenous arachidonic acid was therefore examined. Both PGs increased linearly with increased concentration of melittin in the incubation media. At $20 \mu \mathrm{g}$ melittin $\mathrm{ml}^{-1}$, there was a threefold increase in $\mathrm{PGE}_{2}$ and a sixfold increase in $\mathrm{PGF}_{2 u}$ (Fig. 3). The effect of melittin on PGF production was potentiated by the presence of $\mathrm{Ca}^{2+}$ in the culture medium.

Factors regulating prostaglandin synthesis by bovine spermatozoa

The effect of 8-bromo-cAMP $\left(0-2 \mathrm{mmol} \mathrm{l}^{-1}\right)$ on the conversion of arachidonic acid to $\mathrm{PGE}_{2}$ and $\mathrm{PGF}_{2 \alpha}$ was measured to study the pathway of regulation of $\mathrm{PG}$ synthesis by bovine spermatozoa. PG synthesis was not increased in the presence of 8-bromo-cAMP (data not shown).

The possible role of protein kinase $C$ in the activation of PG synthesis or release of arachidonic acid was determined by investigating the effect of an inhibitor of protein kinase $\mathrm{C}$, staurosporine $\left(10^{-9}-10^{-10} \mathrm{~mol} \mathrm{l^{-1 }}\right)$, on the accumulation of $\mathrm{PGE}_{2}$ and $\mathrm{PGF}_{2 \alpha}$ in the presence of arachidonic acid or melittin (Fig. 4). Prostaglandin synthesis in the presence of arachidonic acid was not affected by staurosporine. In contrast, the stimulatory effect of melittin on PG synthesis was significantly inhibited $\left(P<0.01\right.$ for $\mathrm{PGE}_{2} ; P<0.02$ for $\mathrm{PGF}_{2 \alpha}$ ) by staurosporine in a dose-dependent manner. 


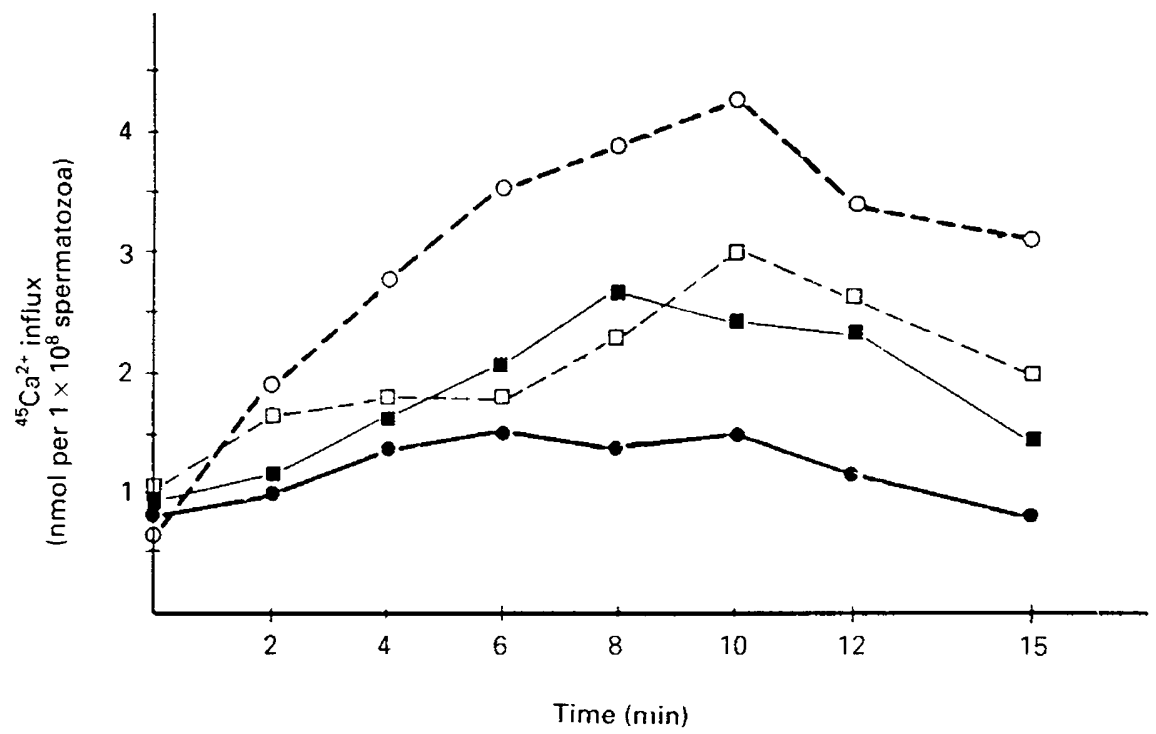

Fig. 8. Effect of prostaglandin $F_{2 a}\left(\mathrm{PGF}_{2 a}\right)$ or indomethacin on calcium uptake by bovine spermatozoa. (O) Control media; (•) $100 \mu \mathrm{g}$ indomethacin $\mathrm{ml}^{-1}$; (口) $100 \mu \mathrm{g}$ indomethacin $\mathrm{ml}^{-1}$ plus $350 \mathrm{pg} \mathrm{PGF}_{2 \alpha} \mathrm{ml}^{-1}$; (ब) $100 \mu \mathrm{g}$ indomethacin $\mathrm{ml}^{-1}$ plus $0.25 \mu \mathrm{g} \mathrm{PGF}_{2 \alpha} \mathrm{ml}^{-1}$.

\section{Western blot analysis of cyclooxygenase}

To determine the presence of cyclooxygenase in the bovine ejaculated spermatozoa, $100 \mu \mathrm{g}$ protein from spermatozoa homogenates were applied to SDS-PAGE and $25 \mu \mathrm{g}$ protein from microsomes from bovine seminal vesicles were used as an internal positive marker for enzyme localization. Five homogenates of bovine spermatozoa samples from different bulls were used. Cyclooxygenase was readily detectable in the spermatozoa homogenates (Fig. 5). The enzyme was also localized in homogenates prepared from caput and cauda epididymal spermatozoa.

\section{Localization of cyclooxygenase in bovine spermatozoa}

Staining with the monoclonal antibody to cyclooxygenase indicated that the enzyme is localized in the apical region of the spermatozoa head, the post-acrosomal region and the midpieces of the tail. No other component in the spermatozoa was stained above background level (Fig. 6).

\section{Role of exogenous prostaglandins in calcium uptake}

Uptake of $\mathrm{Ca}^{2+}$ increased linearly during the first $10 \mathrm{~min}$ of incubation (Fig. 7). In the presence of indomethacin, $\mathrm{Ca}^{2+}$ uptake was inhibited, but this effect was abolished by the presence of exogenous $\mathrm{PGE}_{2}$. In contrast, when spermatozoa were incubated in the presence of exogenous $\mathrm{PGF}_{2 \alpha}(350 \mathrm{pg}$ $\mathrm{ml}^{-1}$ or $\left.0.25 \mu \mathrm{g} \mathrm{ml}^{-1}\right), \mathrm{Ca}^{2+}$ uptake was significantly inhibited (Fig. 8).

\section{Discussion}

In the present study, we report that bovine spermatozoa can produce $\mathrm{PGF}_{2 \alpha}$ and $\mathrm{PGE}_{2}$ in vitro, although the amounts of
$\mathrm{PGF}_{2 \alpha}$ produced were lower than those of $\mathrm{PGE}_{2}$. We have previously shown (Shalev et al, 1992) that intact bovine spermatozoa can synthesize PG and using a specific monoclonal antibody, that cyclooxygenase is localized in the postacrosomal region and the mid-piece of the tail of ejaculated spermatozoa. Furthermore, we demonstrated that arachidonic acid can be metabolized to $\mathrm{PGE}_{2}$ and $\mathrm{PGF}_{2 \alpha}$. Roy and Ratnam (1992) reported that homogenates of human spermatozoa converted arachidonic acid to $\mathrm{PGE}_{2}$ and $\mathrm{PGF}_{2 \alpha}$.

The synthesis of PG by spermatozoa was unaffected by the addition of either $\mathrm{Ca}^{2+}$ or the calcium ionophore, indicating that increasing intracellular or extracellular calcium alone does not affect the rate of synthesis. Calcium ionophore has been shown to activate phospholipase $\mathrm{A}_{2}\left(\mathrm{PLA}_{2}\right)$ in human spermatozoa during the acrosomal reaction (Bennet et al., 1987). However, it is not known whether the concentration of calcium affects the synthesis of PGs in humans.

The release of arachidonic acid is considered to be the rate-limiting step for PG production in most tissues (Irvine, 1982). In particular, two major pathways for arachidonic acid release (Smith, 1989) have been reported. One is the activation of PLA ${ }_{2}$, which causes the release of arachidonic acid directly from esterified stores of phospholipids, and the second is the sequential hydrolysis of phosphoinositide by phospholipase $C$ and glycerol lipases. As both $\mathrm{PGF}_{2 \alpha}$ and $\mathrm{PGE}_{2}$ increased concomitantly with substrate concentration in the incubation media, it appears that cyclooxygenase activity is not a limiting factor in PG synthesis by bovine spermatozoa. PG synthesis was inhibited by indomethacin indicating that cyclooxygenase is involved in the synthesis rather than a non-specific oxidation of arachidonic acid. Activation of $\mathrm{PLA}_{2}$ or protein kinase $\mathrm{C}$ could be the limiting step in the release of arachidonic acid and subsequent PG synthesis. This concept is supported by the observation that the amount of PG produced in the absence of exogenous arachidonic acid was significantly increased by 
adding melittin, which activates $\mathrm{PLA}_{2}$ via protein kinase $\mathrm{C}$ activation. Activation of PLA $\mathrm{A}_{2}$ and phospholipase $\mathrm{C}$ is considered to depend upon intracellular $\mathrm{Ca}^{2+}$ concentrations (Nozawa et al., 1991; Meldurm et al., 1991). It has been reported that activation of protein kinase $C$ enhances arachidonic acid release in canine kidney cells (Silvka and Insel, 1988), human platelets (Halenda et al., 1989) and mouse peritoneal macrophages (Balsinde et al., 1990).

Since it was demonstrated that arachidonic acid is metabolized by bovine spermatozoa, two enzymes (PLA $\mathrm{A}_{2}$ and PKC) that are responsible for the release of arachidonic acid and for which there is good evidence of their presence in mammalian spermatozoa (Breitbart et al., 1992; Hinkovska et al., 1987). (Protein kinase $A$ is apparently not involved in PG synthesis as cyclic nucleotide did not affect PG synthesis.) Melittin, a

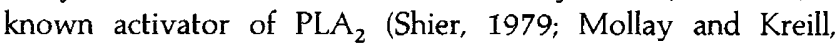
1974; Matsumura and Aketa, 1991), significantly increased PG production in a dose-dependent manner. Since this effect was stimulated by the presence of $\mathrm{Ca}^{2+}$, it appears that $\mathrm{Ca}^{2+}$ is required to activate $\mathrm{PLA}_{2}$ for the release of arachidonic acid. In addition, staurosporine, an inhibitor of PKC (Sako et al., 1988; King and Rittenhouse, 1989), inhibited the effect of mellitin, indicating that PKC activation of $\mathrm{PLA}_{2}$ is a necessary step in PG synthesis by bovine spermatozoa. The inhibitory effect of staurosporin was not seen in the presence of exogenous arachidonic acid, indicating that the increased PG synthesis was due to release of arachidonic acid stores.

We found that exogenous PGE stimulated calcium uptake by bovine spermatozoa. This agrees with the observations of Aitken et al. $(1985,1986)$ who reported that PGE can enhance the penetrating capacity of human spermatozoa into hamster oocytes and is correlated with the ability of PGs to increase intracellular concentration of free extramitochondrial calcium. Aitken and co-workers showed that intracellular calcium increased in the presence of $\mathrm{PGE}_{1}$ and $\mathrm{PGE}_{2}$ but that $\mathrm{PGF}_{2 \alpha}$ had no effect. This suggests that PGE can act as a $\mathrm{Ca}^{2+}$ ionophore. Similarly, Kirtland and Baum (1972) found that PGE, as well as the calcium ionophore A23187, could increase spermatozoa penetration into the zona-free hamster egg.

The data presented here suggest that unknown substances present in seminal fluid (possibly spermine (Shalev et al., 1992)) stimulate protein kinase $C$ activity, which, in turn, activates $\mathrm{PLA}_{2}$. The resultant release of arachidonic acid increases the synthesis of $P G$ via activation of the cyclooxygenase pathway. The data also indicate that the complete machinery required to produce PGs is present in bovine spermatozoa. The system is active and regulated by the same transduction systems seen in other PG producing tissues. However, the localization of cyclooxygenase in spermatozoa (head and midpiece) suggests that PG synthesis has different functions related to its anatomical localization. Synthesis of prostaglandins in the head could be associated with the acrosomal reaction (Joyce et al., 1987), whereas PG synthesis in the midpiece (a mitochondria-rich area) could be involved in energetic metabolic processes related to motility.

The authors thank the Hasherut - Artificial Insemination Center, Israel Cattle Breeders Association Center for supplying them with bull semen.

\section{References}

Aitken RJ and Kelly RW (1985) Analysis of the direct effects of prostaglandins on human sperm function Joumal of Reproduction and Fertility 73 139-146

Aitken RJ, Irvine S and Kelly RW (1986) Significance of intracellular calcium and cyclic adenosine $3^{\prime} 5^{\prime}$ monophosphate in the mechanisms by which prostaglandins influence human sperm function Joumal of Reproduction and Fertility 77 451-462

Babcock DF, First NL and Lardy HA (1976) Action of ionophore A23187 at the cellular level. Separation of effects at the plasma and mitochondrial membranes. Journal of Biological Chemistry 251 3881-3886

Balsinde J, Fernandez B and Diez E (1990) Regulation of arachidonic acid release in mouse peritoneal macrophages Journal of Immunology 144 4298-4304

Ben-Av P, Rubinstein S and Breitbart $H$ (1988) Induction of acrosomal reaction and calcium uptake in ram spermatozoa by ionophores. Biochimica ef Biophysica Acta 939 214-222

Bennet PJ, Moatti JP, Mansat A, Ribbes H, Cayrac JC, Pontonnier F, Chap H and Dauste-Blazy L (1987) Evidence for activation of phospholipases during acrosome reaction of human sperm elicited by A23187 Biochimica et Biophysica Acta 919 255-265

Breitbart H, Lax J, Rotem R and Naor Z (1992) Role of protein kinase C in the acrosome reaction of mammalian spermatozoa. Biochemical Joumal $\mathbf{2 8 1}$ 473-476

Cohen MS, Colin MJ, Golimbu M and Hotchkiss RS (1977) The effect of prostaglandins on sperm motility Fertility and Sterility 28 78-85

Gerozissi K and Dray F (1981) Radioimmunoassay of prostaglandins in the semen of fertile men Journal of Reproduction and Fertility 61 487-490

Halenda SP, Banga HS, Zavoico GB, Lau LF and Feinstein MB (1989) Synergistic release of arachidonic acid from platelets by activators of protein kinase $\mathrm{C}$ and $\mathrm{Ca}^{2+}$ ionophores: evidence for role of protein phosphorylation in the activation of phospholipase $A_{2}$ and independence from the $\mathrm{Na}+/ \mathrm{H}^{+}$ exchanger Biochemistry 28 7356-7363

Harrison FA, Heap RB, Horton EW and Poyser NL (1987) Identification of prostaglandin $\mathrm{F}_{2 a}$ in uterine fluid from non-pregnant sheep with an autotransplanted ovary Journal of Endocrinology 53 215-222

Hayashi S, Noda Y and Mori T (1988) Analysis of the role of prostaglandins in the fertilization process European Journal of Obstetrics and Gynaecology and Reproductive Biology 29 287-297

Hinkovska VTZ, Momchilova AB, Petkova DH and Koumanov KS (1987) Phospholipase $A_{2}$ activity in ram spermatozoa plasma membranes International Joumal of Biochemistry 19 569-572

Irvine RF (1982) How is the level of arachidonic acid controlled in mammalian cells? Biochemical Journal 204 3-16

Izhar M, Pasmanik M, Marcus S and Shemesh M (1992) Dexamethasone inhibition of cyclooxygenase expression in bovine term placenta Prostaglandins $43 \quad 239-254$

Joyce C, Nuzzo NA, Wilson L and Zaneveld LJD (1987) Evidence for the role of cyclooxygenase (prostaglandin synthetase) and prostaglandins in the sperm acrosome reaction and fertilization Journal of Andrology 8 74-82

King WG and Rittenhouse S (1989) Inhibition of protein C by staurosporine promotes elevated accumulation of inositol triphosphates and tetrabisphosphate in human platelets exposed to thrombin Journal of Biological Chemistry $2646070-6074$

Kirtland SJ and Baum $\mathbf{H}$ (1972) Prostaglandin EI may act as a calcium ionophore Nature $23647-49$

LaMaire WJ, Leidner R and Marsh JM (1975) Pre- and post-ovulatory changes in the concentration of prostaglandins in rat Graffian follicles Prostaglandins 9 221-229

Lax Y, Grossman S, Rubinstein S, Magid N and Breitbart H (1990) Role of lipoxygenase in the mechanism of acrosome reaction in mammalian spermatozoa Biochimica et Biophysica Acta 1043 12-18

Levine L (1990) Effects of the protein kinase inhibitors, staurosporine and $\mathrm{K} 252 \mathrm{a}$, on PG12 production by rat liver cells (the C-9 cells line) Prostaglandins $40259-264$

Matsumura K and Aketa K (1991) Does phospholipase $A_{2}$ participate in the acrosome reaction of sea urchin sperm? A pharmacological study Development, Growth and Differentiation 33 365-370

Meizel S and Turner KO (1984) The effects of products and inhibitors of arachidonic acid metabolism on the hamster sperm acrosome reaction Journal of Experimental Zoology 231 283-288

Meldurm E, Parker PJ and Carozzi A (1991) The PtdIns-PLC super family and signal transduction Biochimica et Biophysica Acta 1092 49-71 
Mollay C and Kreill G (1974) Enhancement of bee venom phospholipase $A_{2}$ activity by melittin, direct lytic factor from cobra venom and polymyxin $B$ FEBS Letters 46 141-144

Nozawa Y, Nakashima S and Negata K (1991) Phospholipid-mediated signaling in receptor activation of human platelets Biochimica et Biophysica Acta 1082 219-238

Roy AC and Ratnam SS (1992) Biosynthesis of prostaglandins by human spermatozoa in vitro and their role in the acrosomal reaction and fertilization Molecular Reproduction and Development 33 303-306

Sako T, Tauber AI, Jeng AY, Yupsa SH and Blumberg PM (1988) Contrasting actions of staurosporine, a protein kinase $\mathrm{C}$ inhibitor, on human neutrophils and primary mouse epidermal cells Cancer Research 48 4646-4650

Schlegel W, Rotermund S, Faber G and Neischlag E (1981) The influence of prostaglandins on sperm motility Prostaglandins $2187-99$

Shalev Y, Shemesh M, Marcus S, Rubinstein S and Breitbart H (1992) Localization of cyclooxygenase and production of prostaglandins in bovine sperm Biology of Reproduction, Supplement 146149 (Abstract)
Shemesh M, Milaguir F, Ayalon N and Hansel W (1979) Steroidogenesis and prostaglandin synthesis by cultured bovine blastocysts Journal of Reproduction and Fertility 56 181-185

Shier WT (1979) Activation of high levels of endogenous phospholipase $A_{2}$ in cultured cells. Proceedings National Academy of Sciences, USA 76 195-199

Silvka SR and Insel PA (1988) Phorbol ester and neomycin dissociate bradykinin receptor-mediated arachidonic acid release and polyphosphoinositide hydrolysis in Madin Darby canine kidney cells Joumal of Biological Chemistry $26314640-14647$

Smith WL (1989) The eicosanoids and their biochemical mechanism of action Biochemical Journal 259 315-324

Warnes GM Amato F and Seamark RF (1978) Prostaglandins in the Fallopian tube secretion of the ewe Australian Journal of Biological Science 31 275-282 